\title{
USING HORIZONTAL SUBSURFACE FLOW CONSTRUCTED WETLAND SYSTEM IN THE TREATMENT OF MUNICIPAL WASTEWATER FOR AGRICULTURE PURPOSES
}
M. A. Rahi
Researcher
A.A. H. Faisal
Prof.

Department of Environmental Engineering, College of Engineering, University of Baghdad, ABSTRACT

Iraq.E-mail: munaaziz21@gmail.com; ayadabedalhamzafaisal@yahoo.com

Reuse of treated wastewater for irrigation purpose can reduce high pressure on freshwater resources. A horizontal subsurface flow constructed wetland (HSSF CW) system filled with gravel and planted with Phragmites Australia was used to treat the real wastewater at AlRustumia wastewater treatment plant. Some characteristics of wastewater such as biochemical oxygen demand, phosphate and total suspended solids have been monitored from 15 January until 8 July 2018. The results proved that HSSF unit has a good efficacy in the reduction of previous parameters with removal of 84.2, 55.4 and $72.7 \%$ while sulphate and total dissolved solids were less removal efficiency with 3.3 and $0.99 \%$ respectively. The measured values of these parameters were within the permissible limits suitable for irrigation purposes.

Keywords: water parameter; standard water quality; removal efficiency; irrigation; arid region

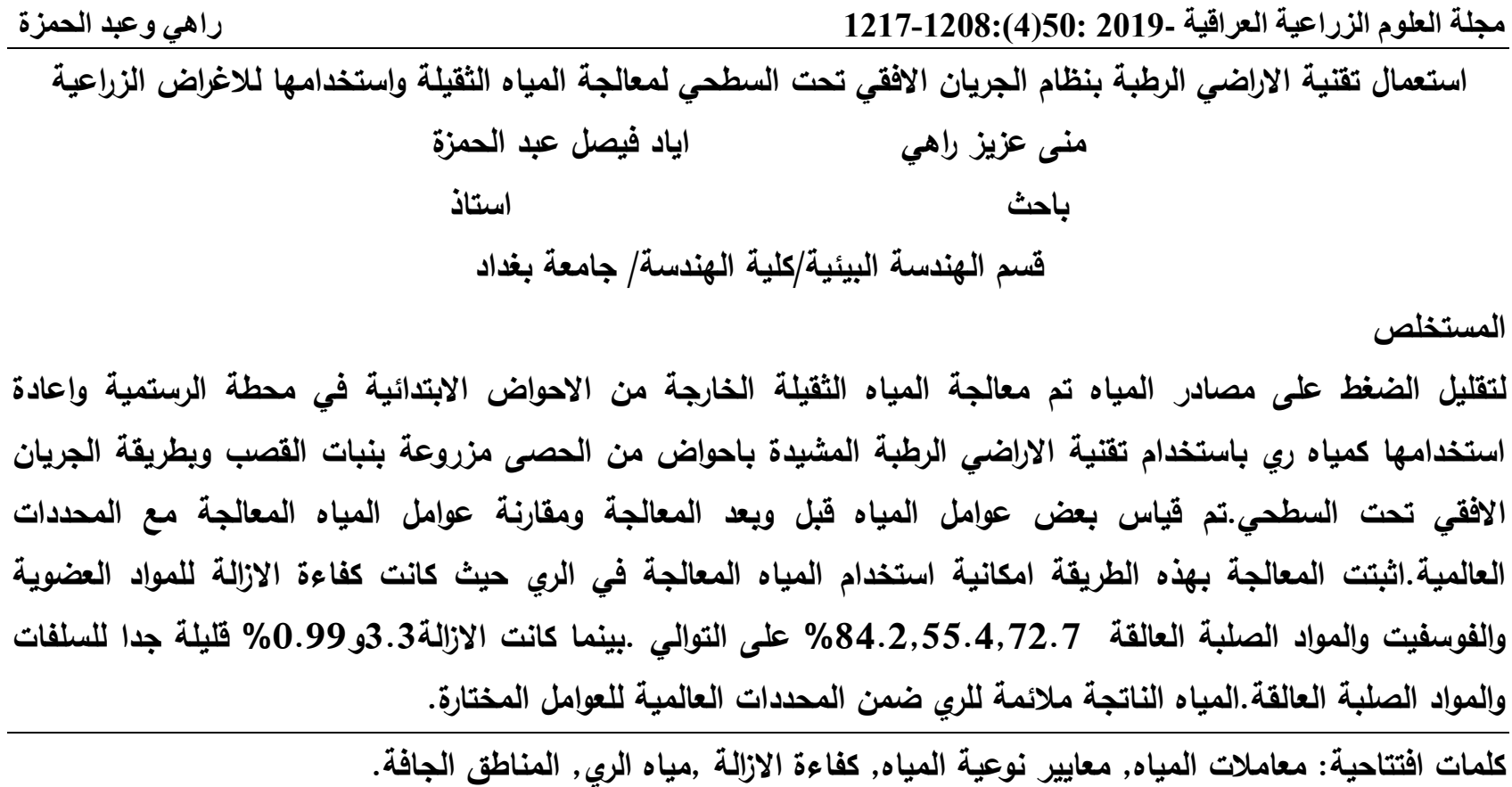




\section{INTRODUCTION}

Constructed wetlands (CWs) are artificial wastewater treatment systems consisted of shallow ponds or channels. These ponds have been planted with aquatic plants. The treatment of wastewater depended upon the natural microbial, biological, physical and chemical processes. Previous studies certified the possibility of using CWs in the effective removal of BOD, and nutrients such as nitrogen and phosphorous (4). When the surface of the water flowing through the system is exposed to the atmosphere, CWs classified as Free Water Surface (FWS) system. Otherwise, the wetland will be Subsurface Flow (SSF) system where no contact of wastewater with the atmosphere (5). SSF can be classified according to their flow patterns into; a) horizontal flow (HSSF) and b) vertical flow (VSSF). System layout, the removal efficiency of pollutants, area requirements, technical complexity, applications and costs are the main differences between the two types (23). Sindilariu employed a HF unit that was packed with gravel and planted with Phragmites, Phalaris, and local swamp-land plants to provide treatment of trout aquaculture. This system received a flow rate between 26.3 and $72 \mathrm{Ls}^{-1}$. Performance analysis indicates BOD and $\mathrm{P}$, removals within $37-49 \%$, and $38-55 \%$ respectively (20). Abou-Elela 2013 investigated the treatment efficiency of two SSF CW pilot plants operated for three years to treat municipal wastewater. A significant removal of COD, BOD and TSS were greater than $90 \%$ in both units (1). Iraq suffered from a severe water shortage especially in summer season due to increase the demands on the limited freshwater supplies. In the future due to the rapid growth of population will affect the demand on the freshwater with increasing generation of wastewater. Conventional wastewater treatment plants (WWTP) required high investment cost, modern technology and high operation energy (15). CWs with their low construction cost, less required efforts for operation and maintenance, low energy consumption as well as their environmental advantage can consider good justifications and alternatives for wastewater treatment (19). The main goal of this research is to investigate the ability of using HSSF CW unit planted with Phragmites australis (common reeds) for municipal wastewater treatment of AlRustumia WWTP, Baghdad, Iraq as an alternative of conventional treatment methods.

\section{MATERIALS AND METHODS}

\section{Site description}

The experimental facility was constructed at Al-Rustumia WWTP, the third expansion project that is located within Baghdad city /

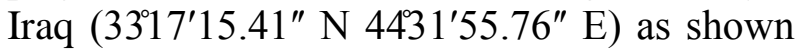
in Figure 1. This location was related with similarity in objectives and environmental circumstances between the sanitary WWTP and the CW, as well as the presence of laboratory building for achieving the planned measurements.

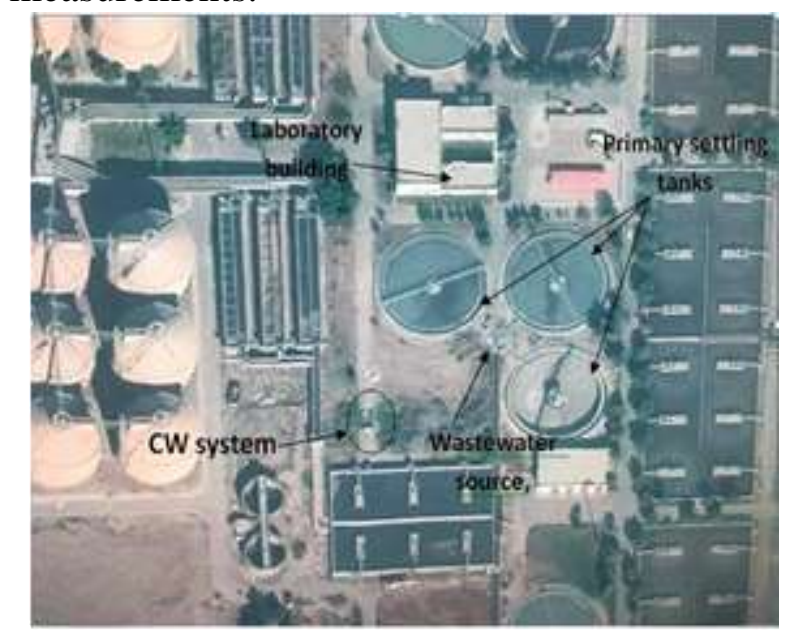

Figure 1. Satellite image for Al-Rustumia WWTP the third expansion project and the location of CWs units

HSSF CWs' start-up, operation, and monitoring

The construction of CW unit was started up at the beginning of October 2017, and lasted for 9 months. The system was designed to capture wastewater by an electrical submersible pump of 1.5 horsepower from the effluent collection point of the three primary basins to ensure that the amounts of suspended solids as low as possible. Then, this wastewater was supplied to the HSSF CW unit from a storage tank by gravity with the aid of necessary appurtenances such as pipes and valves. The unit was operated to allow for plants to grow through the duration of stabilization phase from 1 October to 31 December 2017, where the height of plants reached to $0.7 \mathrm{~m}$. This period is important to establish a compacted bed by ensuring the appropriate growth of 
roots and microorganisms that is suitable for wastewater treatment (19). Then, the testing period was lasting from 15 January to 8 July 2018.

\section{Treatment system design}

The HSSF CW unit was manufactured from steel frame fitted with fiberglass sheets with $(2.85 * 1.2 * 0.8) \mathrm{m}$ length, width, and depth. The basin was filled with medium gravel bed (grain size 8-16 mm) up to a height of $0.6 \mathrm{~m}$. Two compartments of $0.3 \mathrm{~m}$ at the inflow and outflow side was filled with coarse gravel (grain size $40-60 \mathrm{~mm}$; as seen in Figure 2 to protect and avoid potential clogging of the inflow/outflow pipes and to achieve uniform distribution of flow with time.

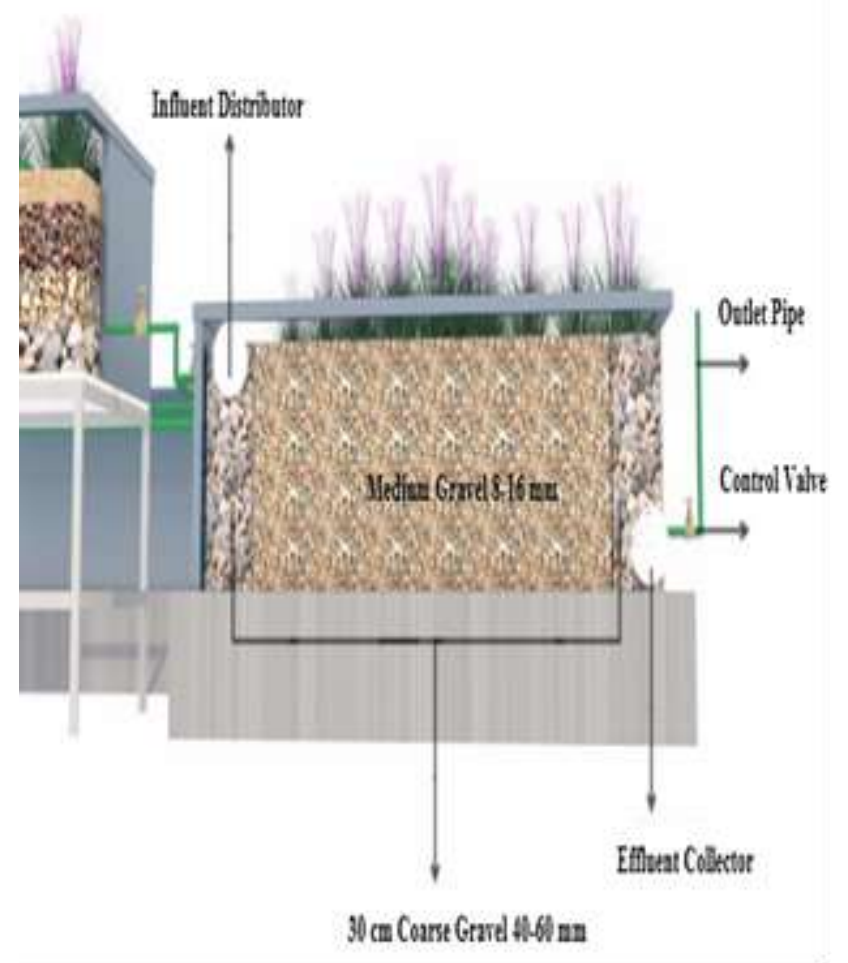

Figure 2. Schematic representation of the pilot-scale wastewater treatment plant using HSSF CW

The design of HSSF CW unit was the same one of the pilot-scale treatment system of Langenreichenbach ecotechnology research facility installed in Germany (18). Healthy specimens of Phragmites australis were trimmed to a height of $0.15 \mathrm{~cm}$ and planted in bed of the experimental unit to ensure the rapid growth during September 2017 with a density of 8 plants $\mathrm{m}^{-2}$ (21).The wastewater was supplied slowly to the bed of $\mathrm{CW}$ through the perforated polypropylene pipe of $100 \mathrm{~mm}$ diameter that placed at the top of the inlet zone. Then wastewater can be collected by another perforated pipe of $100 \mathrm{~mm}$ diameter that was placed in the bottom of the outlet zone. An outlet flow pipe that control the water level within the bed as well as for periodically collection of samples from the effluent was provided.

\section{Wastewater flow rates and retention time estimation}

By using specific surface area of reed bed per inhabitant $\left(0.5-1 \mathrm{~m}^{2}\right.$ capita $\left.^{-1}\right)$ as a simplest method for dimensioning, CWs in Dubai, United Arab Emirates; Haran Al-Awamied, Syria; and Jordan Valley, Jordan have been designed (15). Since the climate of Iraq is hot where the mean annual temperature can be exceeded the $25^{\circ} \mathrm{C}$, then the required specific area can be taken as $0.9 \mathrm{~m}^{2}$.capita ${ }^{-1}$. According to unpublished information obtained from the Ministry of Health and Environment in Iraq, the daily discharge of wastewater was $90 \mathrm{~L}$ capita $^{-1}$ for winter season and increased to become $145 \mathrm{~L}_{\text {capita }}{ }^{-1}$ for summer season, then by dividing the surface area of $\mathrm{CW}$ adopted in the present study (i.e. $3.42 \mathrm{~m}^{2}$ ) on the $0.9 \mathrm{~m}^{2}$ capita $^{-1}$, the result (i.e. $\approx 4$ capita) is represented the number of persons served by this CW unit. By multiplying of values 90 and $145 \mathrm{~L}_{\text {capita }}{ }^{-1}$ with 4 capita, then the volume of water treated by present $\mathrm{CW}$ unit can be specified which equal to 360 and 580 L.day $^{-1}$ for winter and summer seasons respectively. Hydraulic retention time (HRT) is equal to the actual volume of wastewater in the bed $\left(n * L^{*} \mathrm{~W}^{*} \mathrm{D}\right)$ divided by the average design flow ( $Q_{\text {in }}$ in $\mathrm{m}^{3} /$ day). This means that the $H R T=(n * L * W * D) / Q_{\text {in }}=$ $(0.31 * 2.85 * 1.2 * 0.6) / 0.36 \approx 2$ day where: $\mathrm{n}$ represents the porosity of the media. L, W and $\mathrm{D}$ are the length, width and depth of the bed. Many studies proved that 2day is not sufficient to achieve the required nitrification and nitrogen removal especially with the use of new plant (2). Kadlec and Wallace 2009 applied the nominal parameters of a given wetland and this means the use of a nominal detention time $(\tau)$ as an alternative of HRT (14).

The $\tau=(L * W * D) / Q_{\text {in }}$ $(2.85 * 1.2 * 0.6) / 0.36 \approx 5$ days

Where:

L, W and D are the length, width and depth of the bed. 
$Q_{i n}$ is the flow that enter the bed

Five days is more suitable time for organic matter and ammonia removal since the water spends more time in the wetland, the higher the chances for interactions between waterborne substances and the wetland ecosystem (7) .Hydraulic loading rate (HLR) is equal to the inflow rate $\left(Q_{\text {in }}\right)$ divided by the wetland surface area $\mathrm{A}_{\mathrm{s}} H L R=\frac{Q_{\text {in }}}{A_{s}}$

and this means HLR $=0.36 / 3.42=0.105$ m.day 1 for winter season. The value of HLR was increased to become $0.17 \mathrm{~m} \mathrm{day}^{-1}$ for summer season due to increase wastewater flow rate.

\section{Analytical methods}

The chemical parameters such as $\mathrm{BOD}, \mathrm{PO}_{4}-\mathrm{P}$, and $\mathrm{SO}_{4}$ as well as some physical parameters like TSS, TDS and $\mathrm{pH}$ were chosen for evaluating the performance of HSSF. Samples from the inlet and outlet of the $\mathrm{CW}$ were collected in clean plastic bottles of $500 \mathrm{ml}$ and directly transported to the laboratory of the treatment plant for analysis. The, $\mathrm{BOD}, \mathrm{PO}_{4}-\mathrm{P}$, and $\mathrm{SO}_{4}$ were measured according to the standard methods of the American Public Health Association (3) using HACH LANG spectrophotometer/ Germany, while BOD was measured using Lovibond BOD-System OxiDirect / Germany under the manometric principle. The EC, TDS and $\mathrm{pH}$ were measured in electrometric method using WTW InoLab 7110 / Germany, while TSS was measured using gravimetric filtration $(0.45 \mu \mathrm{m}$ pore diameter filter) following 2540-D for TSS dirt at $103-105^{\circ} \mathrm{C}$. Water temperature was recorded by a mercury thermometer. The removal efficiency for each organic and inorganic pollutant (\%) was calculated based on the concentration difference between the effluent and influent relative to the influent by using Microsoft Office Excel.

\section{RESULTS AND DISCUSSION}

During the study period, the monthly air temperature was ranged from 18.3 to $48.3^{\circ} \mathrm{C}$ with mean value of $30.4^{\circ} \mathrm{C}$. The density of the planted reeds in the HSSF CW unit was increased dramatically from 22 on the 15 January to become 108 plants. $\mathrm{m}^{-2}$ in the end of operation period (i.e. 8 July) with a height not less than $1.5 \mathrm{~m}$ as shown in Figure 3. It seems that the parts of reeds were suffered from yellowing and drying which may be due to the rise of temperature during the summer season. This problem can be solved according to Stefanakis et al. 2014 by trimming these parts and added them to the experimental units (21). The characteristics of raw wastewater treated by HSSF CW unit during the period of study are listed in Table 1.

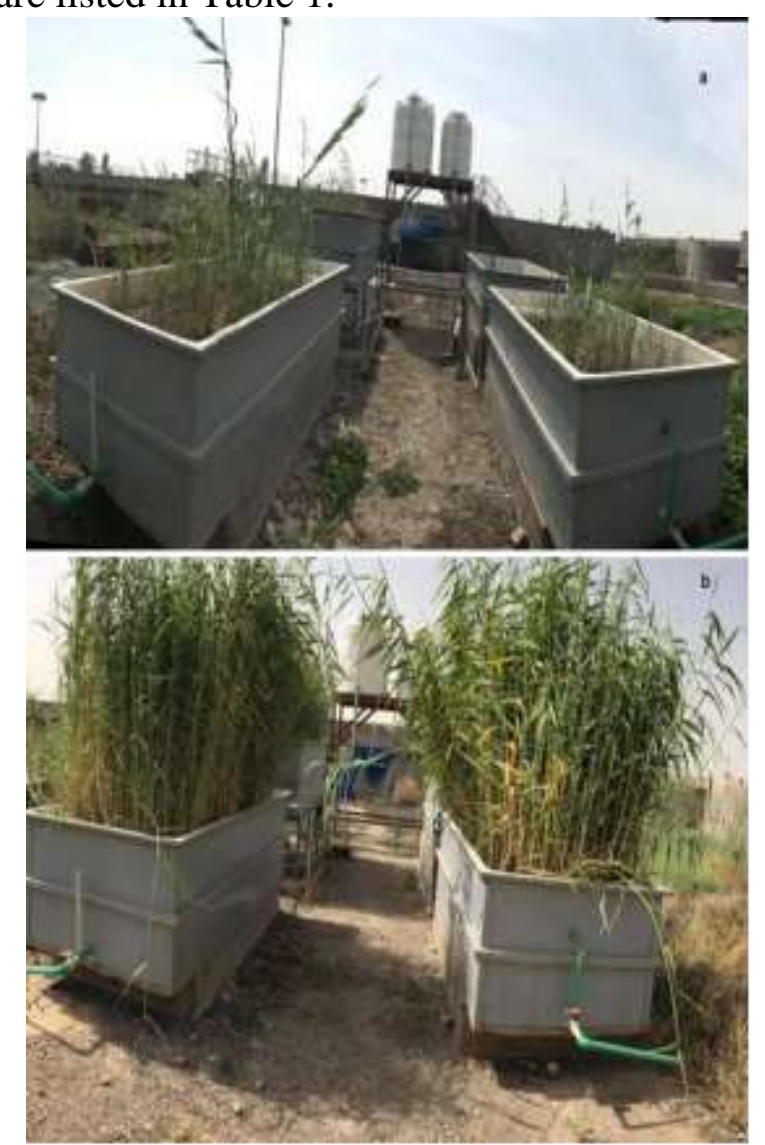

Figure 3. The good growing of Phragmites Australia within the HSSF CW 
Table 1. Overall influent quality in mean value for raw wastewater quality parameters during the whole experiment period (Jan. 2018-Jul. 2018).

\begin{tabular}{|c|c|c|c|c|c|c|}
\hline Parameter & Unit & $\begin{array}{l}\text { No. of } \\
\text { Samples }\end{array}$ & Mean & $\begin{array}{l}\text { Standard } \\
\text { deviation }\end{array}$ & Minimum & Maximum \\
\hline $\begin{array}{l}\text { Biochemical oxygen } \\
\text { demand(BOD) }\end{array}$ & $\mathrm{mgL}^{-1}$ & 12 & 145.5 & 35.71 & 77.0 & 177.0 \\
\hline $\begin{array}{l}\text { Ortho-phosphate- } \\
\text { phosphorus }\left(\mathrm{PO}_{4}-\mathrm{P}\right)\end{array}$ & $\mathrm{mgL}^{-1}$ & 12 & 3.9 & 0.67 & 2.9 & 4.9 \\
\hline Sulphate $\left(\mathrm{SO}_{4}\right)$ & $\mathrm{mgL}^{-1}$ & 12 & 549.3 & 48.57 & 480.0 & 619.0 \\
\hline $\begin{array}{l}\text { Total suspended } \\
\text { solids(TSS) }\end{array}$ & $\mathrm{mgL}^{-1}$ & 12 & 74.7 & 22.89 & 30.0 & 126.0 \\
\hline $\begin{array}{l}\text { Electrical } \\
\text { conductivity(EC) }\end{array}$ & dS.m $\mathbf{m}^{-1}$ & 12 & 3.1 & 0.40 & 2.5 & 3.8 \\
\hline $\begin{array}{l}\text { Total dissolved } \\
\text { solids(TDS) }\end{array}$ & $\mathrm{mgL}^{-1}$ & 12 & 1564.6 & 198.50 & 1240.0 & 1910.0 \\
\hline pH & - & 12 & 7.3 & 0.15 & 7.1 & 7.6 \\
\hline Water temperature & ${ }^{0} \mathrm{C}$ & 12 & 24.2 & 6.00 & 14.4 & 33.8 \\
\hline $\begin{array}{l}\text { Air temperature } \\
\text { (greatest) }\end{array}$ & ${ }^{0} \mathrm{C}$ & 12 & 30.4 & 9.84 & 18.3 & 48.3 \\
\hline $\begin{array}{l}\text { Air temperature } \\
\text { (lowest) }\end{array}$ & ${ }^{0} \mathrm{C}$ & 12 & 15.3 & 8.32 & 3.3 & 30.0 \\
\hline
\end{tabular}

\section{Physical parameters}

Figure 4 is plotted the variation of $\mathrm{pH}$, TSS, and TDS for HSSF CW unit during the operation period. It is clear that the values of $\mathrm{pH}$ were increased after treatment process and these values are greater than the neutral limit with range of $7.5-8$. The increase in $\mathrm{pH}$ values might be related to shifts in the carbon dioxide, alkalinity and $\mathrm{pH}$ relationship as a result of algal consumption of inorganic carbon dioxide from the aqueous media (17), however, the measured values are compatible with acceptable limits specified by FAO (2003) standards (8). The results proved that the TSS have been well removed with mean effluent concentration of $19.7 \mathrm{mgL}^{-1}$ when the mean of the influent concentration equal to
$74.6 \mathrm{mgL}^{-1}$ with removal percentages ranged from 53.3 to $79.6 \%$ during the 12 batch experiments. The steady hydraulic characteristics of the substrate will have a significant role in the creation of a substantial filtering media that able to remove large amounts of solids by sedimentation. Also, microbial metabolism of colloidal solids and electrostatic interaction with electric charges associated with plant roots are additional processes that able to suspended solids settle out through auto and chemical flocculation (17). Figure 4 certifies that the effluent concentrations of TSS are increased in the summer season and this may be due to increase of influent concentration and the breakdown of biofilm (16). 

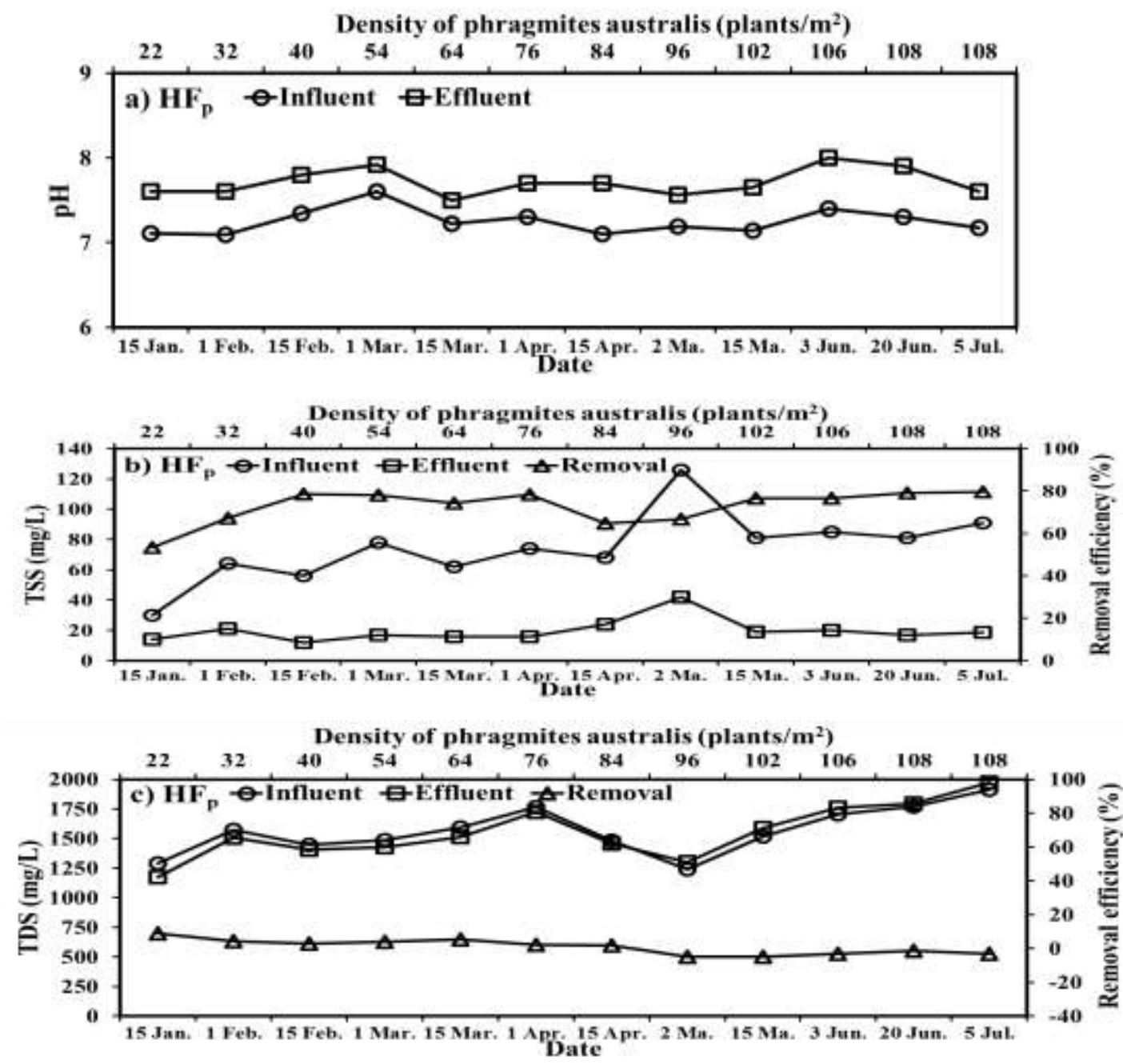

Figure 4. Variation of pH (a), TSS (b) and TDS (c) during the entire operational period for planted horizontal subsurface flow constructed wetland.

The total dissolved solids TDS reflect the salinity variation and the results in Figure 4 signified that their minimum and maximum removal were 1.6 and $8.9 \%$ respectively. However, the effluent TDS concentrations were increased in the summer season and this is very clear through the negative sign (efficiency equal to $-4.8 \%$ ). The TDS removal is regulated by various biogeochemical reactions functioning in the substrate and water column unlike to the suspended or particulate. So, there is no evidence explanation about the behavior of the TDS variation and no description detention time, hydraulic loading could be formed according to the plant nature, plant mature, rate, influent wastewater TDS and temperature or any other factors as described by previous studies such as (16) and (22).
Removal of organic matter (BOD)

The HSSF CW has been successfully used to treat the municipal wastewater as shown in Figure 4 with a wide range of inflow concentrations of organic materials where BOD influent concentrations was 77-177 $\mathrm{mgL}^{-1}$, while the removal efficiency for each parameter not less than $72.6 \%$ and not greater than $91.8 \%$. The results signified that the removal efficiencies of BOD in the HF unit was increased starting from 15 January until 15 March 2018 with percentage not exceeded $25 \%$ and then approximately remain constant, however, this increase may be attributed to the increase of plant density which played a potential role in the requirements of organic matters aerobic degradation especially with the upper layer of the bed approximately 10-20 $\mathrm{cm}$ (22). The aerobic process requires an elevated oxygen supply which is utilized as an 
electron acceptor and Phragmites australis will be the major source of required oxygen. The decrease of dissolved oxygen concentration inside the bed could be enhanced the anaerobic processes of BOD removal. The release of odors from the HSSF CW unit during experimental days is considered a good indicator of the anaerobic decomposition of organic matter by acid- or methane-forming bacteria. The effluent BOD concentrations in February were only greater than the EU limit $25 \mathrm{mgL}^{-1}$ and this can be solved, for example, by increasing the detention time (12). Finally, the results of HSSF CW unit are compatible with previous studies such as (10) and (11).

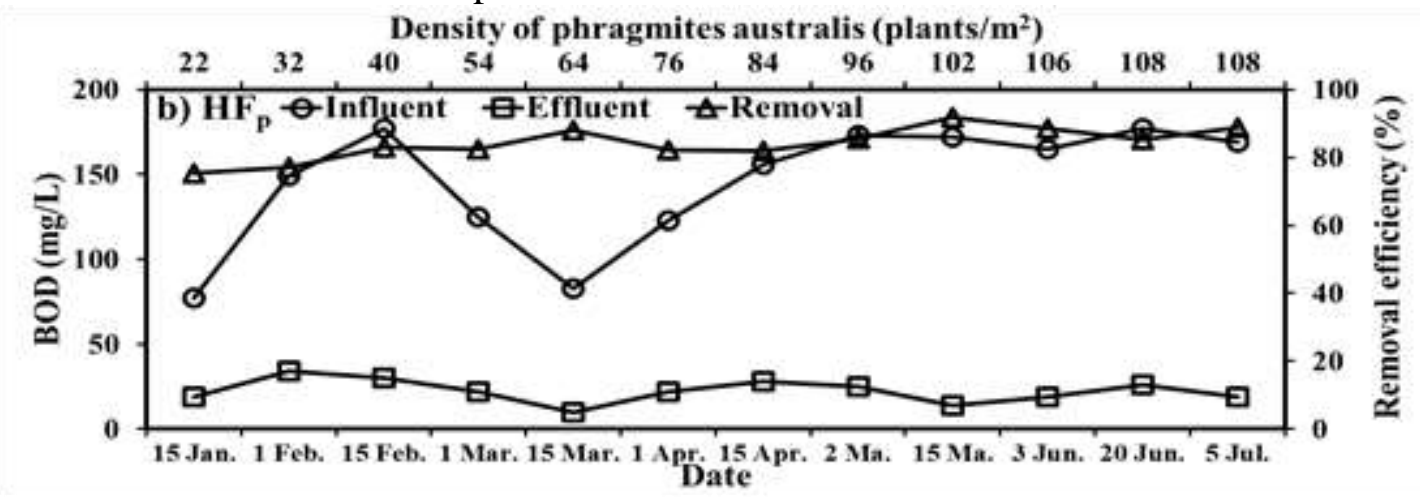

Figure 5. Variation of organic materials during the entire operational period for planted horizontal subsurface flow constructed wetland

\section{Removal of phosphate and sulphate}

Figure 6 illustrates the reduction percentage in the influent concentration of $\mathrm{PO}_{4}^{-3}-\mathrm{P}$ to the HSSF CW unit along the operation period with mean value equal to $55.3 \%$ and the effluent concentrations are not exceeded $2.2 \mathrm{mgL}^{-1}$. Although orthophosphates can be degraded biologically; polyphosphates often undergo hydrolysis process but the commonly removal of phosphorus observed in subsurface flow wetlands is through chemical adsorption to the media that is generally achieved through precipitation of phosphorus as well as the plant and microorganism uptake (24). The mean influent concentration of $\mathrm{SO}_{4}^{-}$was equal to $549.3 \mathrm{mgL}^{-1}$ and the HSSF CW unit showed an evidence fluctuation in the removal efficiency of this parameter which decreased with percentages ranged from 0.5 to $16.7 \%$ (Figure 6). The present fluctuations can be resulted from processes occurring within the unit such nitrification, sulphide oxidation, denitrification and sulphate reduction that can occur simultaneously in the rhizosphere of treatment wetlands caused by dynamic redox gradients (aerobic-anaerobic) conditions (9). In addition, the process of denitrification occurred by microorganisms can be another reason for this fluctuation that caused nitrate reduction to $\mathrm{N}_{2}$ and allowed the oxidation of sulphide to sulphate (6). 

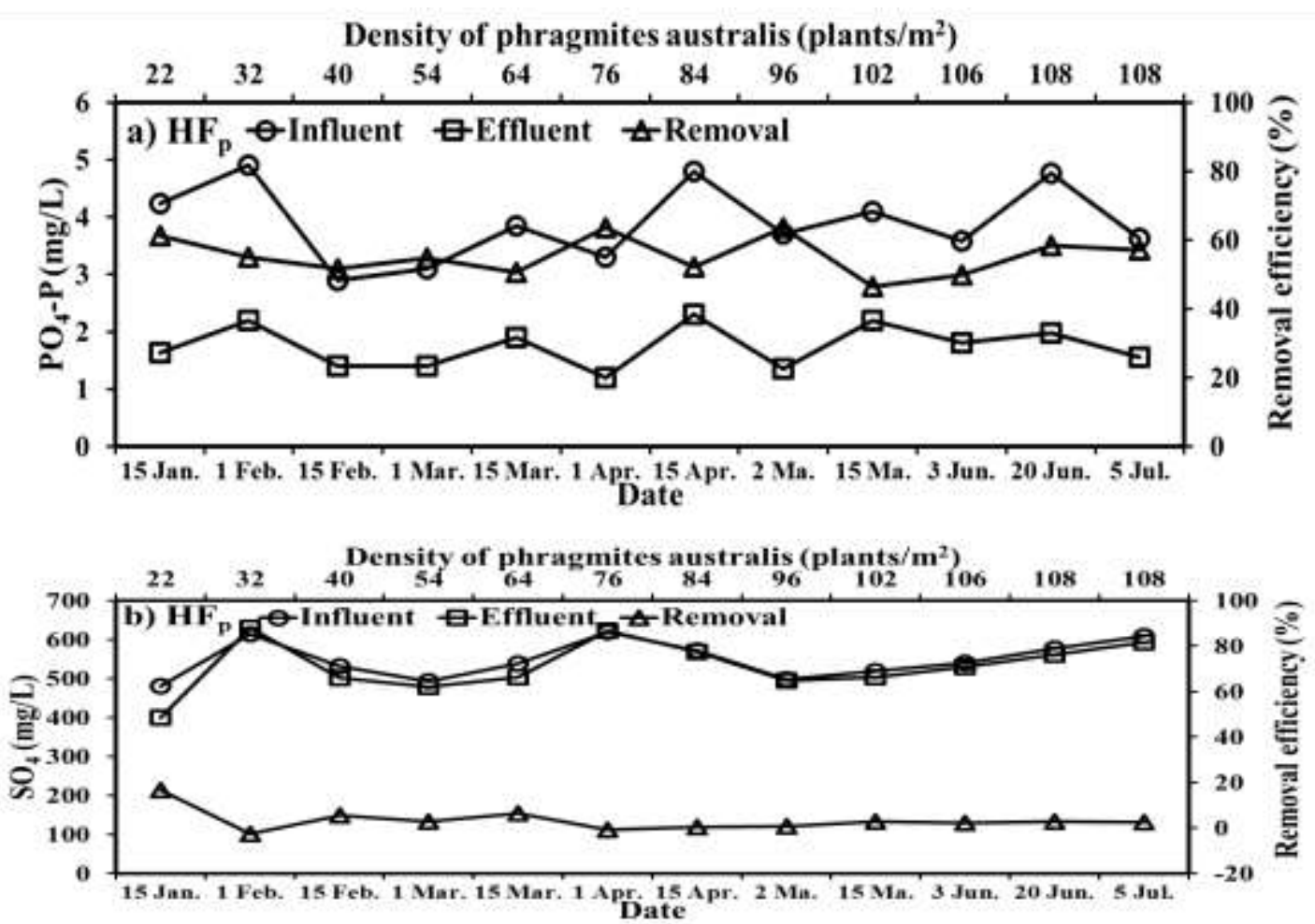

Figure 6. Variation of phosphate (a) and sulphate (b) during the entire operational period for planted horizontal subsurface flow constructed wetland.

\section{Quality of treated wastewater}

Table 2 elucidates the comparison between the HSSF CW unit effluent concentration for measured parameters and the permissible limits for treated wastewater used in agriculture purposes adopted by France, WHO, FAO and USEPA. This table indicated that the salinity of the treated water is within the acceptable standards, generally, if the EC of irrigation water is below $0.7 \mathrm{dS} . \mathrm{m}^{-1}$, it has not negative effect on the crop growth; when EC above $3 \mathrm{dS} \cdot \mathrm{m}^{-1}$, this can cause a severe damage for crop (13). Previous studies proved that the TSS does not have adverse effects on the irrigation facilities. Table 2 shows that the France standards specified that this parameter must be less than 15 to use of treated water for processed food crops. Also, the $\mathrm{pH}$ values of treated water were within the permissible limits and this water can be applied to stream, lake, and groundwater. Concerning BOD, The quality of treated wastewater is compatible with irrigation requirements where mean effluent BOD is $22.3 \mathrm{mgL}^{-1}$, so there is no negative effect of BOD on the growing of food crops as shown in Table 2. The water used in the irrigation may be contained a high proportion of the slightly ions and salts such as $\mathrm{PO}_{4}-\mathrm{P}$, calcium, bicarbonate and sulphate where these salts might be caused clogging for the irrigation equipment due to the stimulation of bacteria or algae growth. (7) The present results proved that the $\mathrm{HSSF} \mathrm{CW}$ unit can play a good role in the reduction of $\mathrm{PO}_{4}-\mathrm{P}$ concentrations which are acceptable for irrigation under the limits of FAO. Finally, the concentrations of sulphate in the wastewater treated by HSSF CW unit were within the acceptable limits and this is very clear in the Table 2. 
Table 2. Comparison between measured parameters with irrigation water quality guidelines and standards for wastewater reuse in the agriculture sector

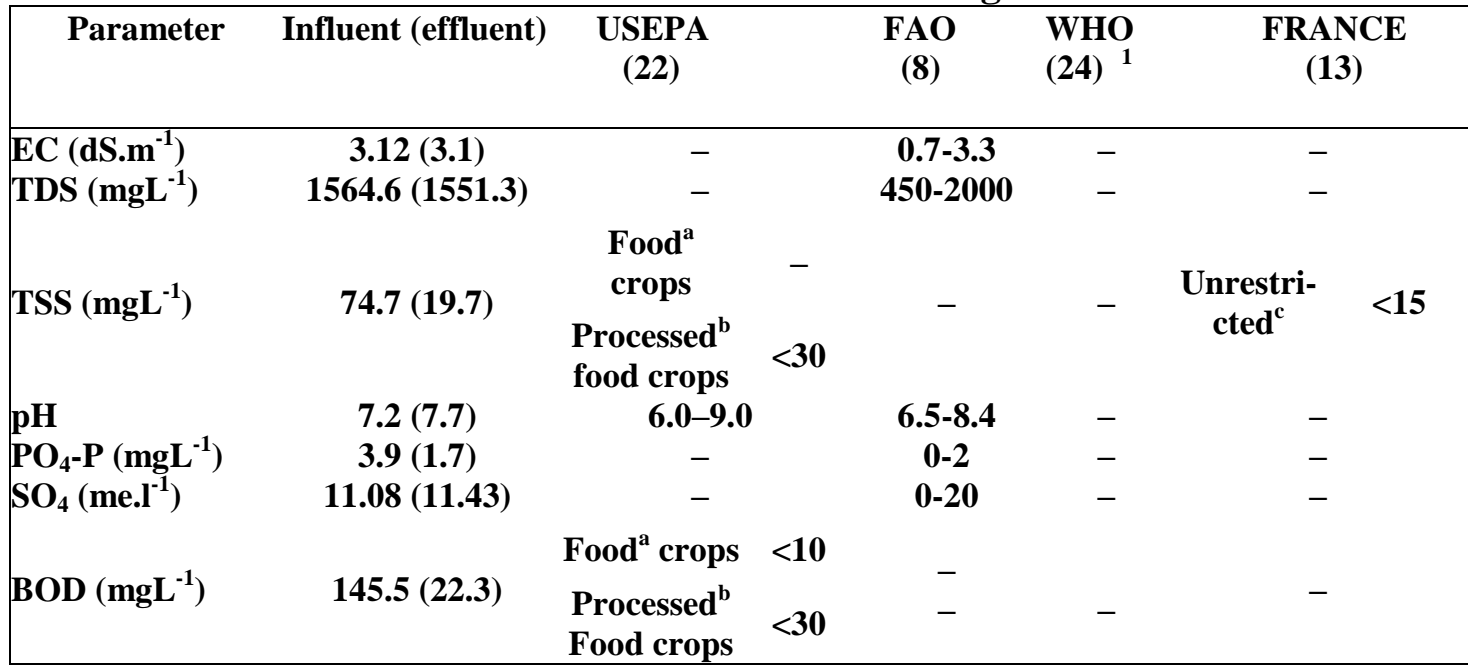

1-The most stringent verification monitoring level, which refers to what has previously been referred to as effluent guideline levels, for each irrigation type and arithmetic mean value. a- Food crops: The use of reclaimed water to irrigate food crops that are intended for human consumption. b- Non-food crops and processed food crops: The use of reclaimed water to irrigate crops that are either processed before human consumption or not consumed by humans. c- Use of treated wastewater to grow crops that are normally eaten raw. The result proved that there is a dramatic growth in the used plants which was increased from 22 to 108 plants/m2with height not less than 1.5 $\mathrm{m}$ through the operation period started from 15 January until 8 July 2018. The biofilm and plants as well as other physical and chemical process may play a significant role in the treatment process. The HSSF CW technology proved its ability in the achievement a satisfactory treatment for real municipal wastewater which enhanced that using of this sustainable technique can consider as an alternative of conventional wastewater treatment technique especially in the rural areas where it is difficult to connect of these areas to the sewerage system. The results proved that the removal efficiencies achieved using HSSF CW unit have good values. These values were, 84.2, 55.4 and $72.7 \%$ for BOD, $\mathrm{PO}_{4}-\mathrm{P}$, and TDS respectively. After considering the permissible limits for water required, the present treated wastewater can be used effectively in the irrigation process as a supporting source for freshwater.

\section{REFERENCES}

1. Abou-Elela, S. I., G. Golinielli, E. M. Aboutaleb and M. S. Hellal, 2013. Municipal wastewater treatment in horizontal and vertical flows constructed wetlands. Ecological Engineering, Elsevier B., 61: 460-468

2. Almuktar, S., S. N. Abed, , and M.Scholz, 2018a. Wetlands for wastewater treatment and subsequent recycling of treated effluent: a review. Environmental Science and Pollution Research, 25(24), 23595-23623

3. American Public Health Association 2012: Standard Methods for the Examination of Water and Wastewater $22^{\text {nd }}$ edition. Am water Work Assoc Water Environ Fedration, Washingt DC

4. Andreo-Martínez, P., N.García-Martínez and L.Almela 2016. Domestic wastewater depuration using a horizontal subsurface flow constructed wetland and theoretical surface optimization: a case study under dry mediterranean climate. Water, 8(10), 434-452

5. Brix, H. 2003. National experiences, Danish experiences with wastewater treatment in constructed wetlands. $1^{\text {st }}$ international seminar on the use of aquatic macrophytes for wastewater treatment in constructed wetlands, Department of Plant Ecology, Institute of Biological Sciences, University of Aarhus, Nordlandsvej Risskov, Denmark,68(8240): 137.

6. Doktoringenieur, G., H. S. Lsa, , A. Enrique, G. Mosquera, and K.Verteidigung 2008. On Possibilities of the Post - Treatment of Anaerobic Digester Effluents with High $\mathrm{H}_{2} \mathrm{~S}$ Loads in Constructed Wetlands. Ph.D. Dissertation submitted to the Center for 
Engineering, Faculty of Science and Engineering, The Martin Luther University, Halle Wittenberg, , Grundordnung. pp: 42-57

7. EPA, Agency 1993. Subsurface Flow Constructed Wetlands For WasteWater Treatment A Technology Assessment. Office Of Water (4204), EPA 832-R-93-008, https://nepis.epa.gov/Exe/ZyNET.exe/2000475 $\underline{\text { V.TXT }}$

8. FAO, Food and Agriculture Organazation of the U.Nation 2003. Users manual for Irrigation with Treated Wastewater. pp: 62-71. http://www.fao.org/3/T0551E/t0551e07.htm

9. Gonzalias, A. E., P. Kuschk, A. Wiessner, M. Jank, M. Kästner, , and H. Köser 2007. Treatment of an artificial sulphide containing wastewater in subsurface horizontal flow laboratory-scale constructed wetlands. Ecological Engineering, 31(4), 259-268

10. Hayder, S., H. Haider, O. Nadeem, , G. Hussain, S. Zahra, R. Planning and U. Student 2015. Proposed model for wastewater treatment in Lahore using constructed wetlands. Journal of Faculty of Engineering and Technology Journal. JFET 22 (1), 07-17

11. Herouvim, E. S. 2011. Treatment of olive mill wastewater in pilot-scale vertical flow constructed wetlands. Ecological Engineering, 37(6), 931-939

12. Hijosa-Valsero, M., R. Sidrach-Cardona and E. Bécares 2012. Comparison of interannual removal variation of various constructed wetland types. Science of the Total Environment, Elsevier B.V., 430, 174183

13. Jeong, H., H. Kim, and T.Jang 2016. Irrigation water quality standards for indirect wastewater reuse in agriculture: A contribution toward sustainablewastewater reuse in South korea. Water Switzerland, 8(4), 169-187

14. Kadlec R. and S.Wallace 2009. Treatment Wetlands. Second Edition. https://sswm.info/sites/default/files/reference_ attachments/KADLEC\%20WALLACE\%2020 09\%20Treatment $\% 20$ Wetlands $\% 202$ nd $\% 20 \mathrm{Ed}$ ition_0

15. Münch, E. Von. 2009. Compilation of 24 SuSanA case studies- pre-print forthe10thsusana meeting. Sustainable Sanitation Alliance c/o German Technical Cooperation

Agency. https://smartnet.niua.org/sites/default/files/reso urces/2-1937

16. Nivala, J., T.Headley, S. Wallace, K.Bernhard, , H. Brix, M. Van Afferden and R. Arno 2013. Comparative analysis of constructed wetlands: The design and construction of the ecotechnology research facility in Langenreichenbach , Germany. Ecological Engineering, Elsevier B.V., 61, 527-543.

17. Okurut, T. O. 2000. A Pilot Study on Municipal Wastewater Treatment Using a Constructed Wetland in Uganda. Ph.D. Dissertation, CRC Press; $1^{\text {st }}$ ed , pp:184

18- Pimentel, D., B. Berger, D. Filiberto, M. Newton, B.Wolfe, E. Karabinakis, S. Clark, E.Poon, E. Abbett and S.Sudha Nandagopal 2004. Water Resources: Agricultural and Environmental Issues. BioScience, 54(10), 909-918.

19. Poulson, T., R. Rhodes, J. Bays, and M. Hwang, 2012. Regulating Wetlands Pilot Study for Concentrate Management. (3699), 72.

https://www.usbr.gov/research/projects/downl oad_product.cfm?id=520.

20. Sindilariu, P. D., A. Brinker and R. Reiter 2009. Factors influencing the efficiency of constructed wetlands used for the treatment of intensive trout farm effluent. Ecological Engineering. 35(5), 711-722

21. Stefanakis, A. I. and V. Tsihrintzis, 2012. Effects of loading, resting period, temperature, porous media, vegetation and aeration on performance of pilot-scale vertical flow constructed wetlands. Chemical Engineering Journal. 181-182, 416-430

22. USEPA, Guidelines for Water Reuse 625/R-04/108; Environmental Protection Agency:, Washington, DC, USA, 2004

23. Vohla, C., M. Kõiv, H. Bavor, F. Chazarenc and Ü. Mander, 2011. Filter materials for phosphorus removal from wastewater in treatment wetlands-A review. Ecological Engineering. 37(1), 70-89

24. WHO. 2004 . Guidelines for Drinkingwater Quality. Volume 1. Recommendations. World Health Organization, Geneva. https://apps.who.int/iris/handle/10665/42852. 